\begin{tabular}{cccc} 
VERSITA & GOSPODARKA & SUROWCAMI & MINERALNYMI \\
\hline Tom 29 & 2013 & Zeszyt 1 \\
& DOI 10.2478/gospo-2013-0009 &
\end{tabular}

\title{
Methane emissions from ventilation and degasification systems of hard coal mines in Poland in the years 2001-2010
}

\section{Introduction}

This analysis was based on statistics compiled by the Central Mining Institute (CMI) in the form of the Annual Report... (2002-2011). It specifies data on hard coal output, absolute methane emissions, methane drainage, and methane management for mines in the Upper Silesian Coal Basin (USCB) in the years 2001-2010. For each of the analysed years it was possible to define output quantities from mines classified as Coal Mine Methane (CMM). The number and output of mines defined as CMM mines have been estimated on this basis. In conformity with the Annual Report...(2002-2011), methane - and the explosion hazard connected with it - is one of the most dangerous phenomena accompanying hard coal production in the Polish mining industry. The classification of coal seams in Polish mines according to the appropriate methane hazard category is determined by the Order of the Minister of Internal Affairs and Administration of 14 June 2002 on natural hazards in mines (Order... 2002).

Generally, the areas of methane emissions in a mine can be systematised due to the level and dynamics of methane emissions in the following order: winning operations, gobs, development operations, active roadway excavations (Konopko, ed. 2010).

* Dr inż., Zakład Tapań i Mechaniki Górotworu, Główny Instytut Górnictwa, Katowice; e-mail: r.patynska@gig.eu 


\section{Characterization of methane emissions in the USCB}

In the years 2001-2010, exploitation of coal seams in Poland was conducted in mines specified in the Annual Report... (2002-2011). In this year's report, the number of operating hard coal mines in Poland was reduced from 43 in 2001 to 29 in 2010. Production output decreased from $102.78 \cdot 10^{6} \mathrm{Mg}$ to $76.15 \cdot 10^{6} \mathrm{Mg}$. It should be noted that the reduction in the number of mines included the joining of neighbouring mines, which also influenced the decrease in the number and output from CMM mines. In the year 2001, 30 CMM mines produced $72.37 \cdot 10^{6} \mathrm{Mg}$, while in the year 2010,21 mines produced $52.18 \cdot 10^{6} \mathrm{Mg}$ of coal (Table 1).

Polish hard coal deposits, especially in the central, southern, and southwestern part of the USCB, belong in the category with high methane content (Annual Report... 2002-2011; Konopko, ed. 2010). The Carboniferous deposits are covered by an overburden of non-permeable Miocene layers of great thickness which prevent the methane from escaping the coal seams. This high gas content creates a hazard while conducting mining operations. Methane emissions from Polish hard coal mines concern:

- areas of mined longwalls (i.e. they originate from the mined seam as well as from underworked and overworked seams decompressed as a consequence of longwall mining); methane from underworked and overworked seams is emitted to post-mining gobs;

Hard coal output in CMM coal mines in the years 2001-2010

TABELA 1

Wydobycie kopalń węgla kamiennego w latach 2001-2010

\begin{tabular}{||c|c|c|c|c||}
\hline Year & $\begin{array}{c}\text { Hard coal output } \\
\text { in coal mines } \\
{\left[10^{6} \mathrm{Mg}\right]}\end{array}$ & $\begin{array}{c}\text { Number } \\
\text { of coal mines }\end{array}$ & $\begin{array}{c}\text { Hard coal output } \\
\text { in the CMM coal mines } \\
{\left[10^{6} \mathrm{Mg}\right]}\end{array}$ & $\begin{array}{c}\text { Number of CMM } \\
\text { coal mines }\end{array}$ \\
\hline \hline 2001 & 102.78 & 43 & 72.37 & 30 \\
\hline 2002 & 102.07 & 42 & 72.13 & 29 \\
\hline 2003 & 100.41 & 41 & 65.71 & 29 \\
\hline 2004 & 99.17 & 41 & 69.17 & 24 \\
\hline 2005 & 97.17 & 35 & 67.35 & 23 \\
\hline 2006 & 94.27 & 31 & 64.52 & 23 \\
\hline 2007 & 87.4 & 31 & 62.47 & 23 \\
\hline 2008 & 83.4 & 29 & 57.54 & 21 \\
\hline 2009 & 77.27 & 30 & 53.27 & 2.18 \\
\hline 2010 & 76.15 & 29 & & \\
\hline \hline
\end{tabular}


- post-mining gobs (isolated from active mine excavations by explosion-proof dams in the neighbourhood of isolation dams and fractures in the rock mass through which methane is emitted into the excavations); methane from post-mining gobs in some mines is captured by the method of methane drainage;

- drilled development excavations.

Methane from the seam where both development and winning operations are conducted migrates into the mine atmosphere. From these seams methane cannot be captured using the method of methane drainage. Only $3 \%$ of the total amount of methane captured by means of methane drainage originates from advancing methane drainage conducted in driven roadway excavations.

Generally, advancing methane drainage in Polish hard coal mines below the depth of $400 \mathrm{~m}$ is characterised by low capture effectiveness. The gas permeability of seams in the USCB is very low, resulting in difficult methane flow in the coal matrix of the seam in which mining operations are conducted. By comparison, coal in mines in the United States of America or Australia have permeability about 50 times higher than coals in the USCB. In these countries, pre-mining methane drainage is conducted even by means of boreholes drilled from the surface.

Methane capturing from seams in the USCB in which exploitation is planned results in a seam of considerably lower methane saturation during exploitation.

The end of mining operations does not terminate methane emissions into excavations from decompressed, underworked and overworked seams. The model of methane emissions from longwall gobs, after the end of exploitation, was included in the Instruction... (2000). The quantity of methane emissions into the excavations of an abandoned mine depends on:

- the average weighted methane content of the exploited deposit,

- the volume of decompressed, overworked and underworked seams,

- the time of abandoned mine flooding,

- the height of the column of water above underworked and overworked seams.

In spite of considerable progress in the recognition and fighting of the methane hazard, increases in this problem have been observed in maning mining areas in Poland. This is connected with the increasing depth of conducted exploitation, higher methane content of seams, and gas deposit pressure. Exploitation at greater depths in seams highly saturated with methane has seen a cumulative effect of the quantity of emitted methane in a smaller number of longwall workings and thus the growth in their absolute methane emissions.

The statistics on mining catastrophes caused by methane or methane and coal dust explosions in the history of the Polish underground mining sector is the most tragic on record, both in terms of the number of fatalities and serious accidents as well as the resulting material damages (Kidybiński, Patyńska 2008; Patyńska 2010). Methane causes also negative ecological effects in cases where it is carried away directly by the ventilation air into the atmosphere.

Investigations into past methane explosions contributed to the development of means of recognizing and predicting the methane hazard, the extension of controls on the methane 
content in the air of excavations, as well as the development of methods to combat the presence of methane including methane drainage. Correct recognition of the state of the methane hazard and efficiently fighting it are of fundamental significance in conducting safe exploitation (Konopko, ed. 2010).

Taking the above-mentioned factors into consideration, the CMI annually prepares a report about the state of the methane hazard in the Polish mining industry. Using the data presented in the present Annual Report... (2002-2011), Table 2 specifies data related to the output and quantity of emitted methane from individual mines. It should be noted, in the Polish coal mining industry in the years 2001-2010, one mine was closed namely the Niwka-Modrzejów colliery. In spite of this fact, measurements of methane emissions were performed until the year 2002. The results of measurements from the years 2001-2002 were taken into consideration in the annual calculations and specifications of the estimated ventilation emissions.

The data specified in Table 2 make it possible to state that, in spite of the drop in coal production and the decreasing number of mines in the USCB, methane emissions from coal exploitation processes in CMM mines since 2001 had increased by about $50 \mathrm{~m}^{3} / \mathrm{Mg}$ in 2010 . With the passage of time, the efforts at methane drainage brought positive effects. Every year, the quantity of methane captured by methane drainage systems and the quantity of utilized methane grows.

TABLE 2

Methane emission in hard coal mines (active and abandoned) from the years 2001-2010

TABELA 2

Metanowość węgla kamiennego kopalń (aktywnych i zlikwidowanych) w latach 2001-2010

\begin{tabular}{|c|c|c|c|c|c|}
\hline Year & $\begin{array}{c}\text { Hard coal } \\
\text { output in the } \\
\text { CMM coal } \\
\text { mines } \\
{\left[10^{6} \mathrm{Mg}\right]}\end{array}$ & $\begin{array}{l}\text { Relative methane emissions } \\
\text { from active coal mines - } \\
\text { mining ventilation methane } \\
\text { emission } \\
{\left[\mathrm{m}^{3} / \mathrm{Mg}\right]}\end{array}$ & \begin{tabular}{|} 
Relative methane \\
emissions from \\
degassing \\
systems \\
{$\left[\mathrm{m}^{3} / \mathrm{Mg}\right]$} \\
\end{tabular} & $\begin{array}{c}\text { Relative } \\
\text { methane } \\
\text { emissions - } \\
\text { loss emissions } \\
{\left[\mathrm{m}^{3} / \mathrm{Mg}\right]} \\
\end{array}$ & $\begin{array}{c}\text { Absolute } \\
\text { methane } \\
\text { emissions from } \\
\text { abandoned mines } \\
{\left[10^{6} \mathrm{~m}^{3} / \text { year }\right]} \\
\end{array}$ \\
\hline 2001 & 72.37 & 300.22 & 82.74 & 30.71 & 0.91 \\
\hline 2002 & 72.13 & 304.08 & 78.11 & 30.91 & 0.73 \\
\hline 2003 & 65.71 & 345.69 & 92.08 & 40.57 & - \\
\hline 2004 & 69.17 & 320.26 & 91.14 & 38.41 & - \\
\hline 2005 & 67.35 & 287.98 & 87.57 & 37.23 & - \\
\hline 2006 & 64.52 & 305.62 & NA & NA & - \\
\hline 2007 & 62.47 & 325.56 & 101.33 & 38.20 & - \\
\hline 2008 & 57.54 & 361.11 & 116.40 & 51.15 & - \\
\hline 2009 & 53.27 & 385.35 & 120.09 & 43.18 & - \\
\hline 2010 & 52.18 & 350.78 & 110.82 & 38.58 & - \\
\hline
\end{tabular}




\section{Methane emissions inventory in Polish mines}

The National Inventory Report on Greenhouse Gas Emissions and Absorption for 2007 (NEIC 2009) was published in Poland in 2009, and prepared in order to fulfil Poland's obligations in conforming with the requirements of the European Parliament and for implementing the Kyoto Protocol... (1997), as well as for meeting the needs of the United Nations Framework Convention on Climate Change (UNFCCC). The report of the NEIC (2009) presents the results of a national inventory of greenhouse gas emissions and absorption in Poland in 2007, including methane $-\mathrm{CH}_{4}$. The guidelines for the calculation of emissions and absorption of greenhouse gases are consistent with the methods recommended in the basic publications of the Intergovernmental Panel on Climate Change (IPCC 1997, 2000).

The NEIC (2009) indicated there was no detailed data concerning methane emissions in collieries in the Polish mining industry. As a result, methane emissions in coal mines of the USCB in Poland were studied and meticulously calculated. In conformity with the IPCC (2006) guidelines then in force, in order to obtain more accurate data about emissions where it was possible, national methods of emissions estimation were used.

The report of the NEIC (2009) indicated methane emissions in Poland in 2007 for Solid Fuels, including hard coal, amounted to $410.05 \mathrm{Gg}$, constituting $23.77 \%$ of the share in individual categories of the national $\mathrm{CH}_{4}$ emissions. Methane emissions (without category 5) in 2007 amounted to $1,725.01 \mathrm{Gg}$, i.e. $36.23 \mathrm{Gg}$ of $\mathrm{CO}_{2}$ equivalent. The share of methane in the total national greenhouse gas emissions in 2007 amounted to $9.1 \%$. The emissions of the first of the mentioned categories included, among other things, emissions from underground mines (about $23.8 \%$ of total $\mathrm{CH}_{4}$ emissions).

Using the results of two methodological works, national emission factors for the following emission sources in hard coal mines were determined (Gawlik et al. 1994; Gawlik, Grzybek 2001; SGI 2008):

— from ventilation systems,

- from methane drainage systems,

- from mined out coal from post-exploitation (post-extraction) processes.

Table 3 presents the national emissions inventories factors hitherto used for individual emission types. Also, the results from the work of Kwarciński et al. (2005) were specified in the table, which once again estimated the emissions factors on the basis of very detailed data and measurements for the year 2003. Furthermore, a thorough analysis of emission factors was carried out, comparing them with the results of previous works. For the needs of the national inventory, the emission factors per $\mathrm{Mg}$ of mined coal were calculated - these values are generally available, for example, from the publication of the State Geological Institute (SGI 2008).

After the analysis, selection of emission factors was carried out for ventilation systems, methane drainage (degasification) systems, post-exploitation (post-extraction) processes, production wastes, and from abandoned mines for individual years in the period 1988-2007, 
Methane emission factors

Wskaźniki emisji metanu

\begin{tabular}{||c|c|c|c|c|c|c||}
\hline \multirow{2}{*}{ Emissions } & \multicolumn{2}{|c|}{ Acc. Gawlik et al. 1994 } & \multicolumn{2}{c|}{ Acc. Gawlik, Grzybek 2001 } & \multicolumn{2}{c||}{ Acc. Kwarcínski et al. 2005 } \\
\cline { 2 - 7 } & $\begin{array}{c}\mathrm{Nm}^{3} \mathrm{CH}_{4} / \mathrm{Mg} \\
\text { of coal }\end{array}$ & $\begin{array}{c}\mathrm{Gg} \mathrm{CH}_{4} / \mathrm{Mg} \\
\text { of coal }\end{array}$ & $\begin{array}{c}\mathrm{Nm}^{3} \mathrm{CH}_{4} / \mathrm{Mg} \\
\text { of coal }\end{array}$ & $\begin{array}{c}\mathrm{Gg} \mathrm{CH}_{4} / \mathrm{Mg} \\
\text { of coal }\end{array}$ & $\begin{array}{c}\mathrm{Nm}^{3} \mathrm{CH}_{4} / \mathrm{Mg} \\
\text { of coal }\end{array}$ & $\begin{array}{c}\mathrm{Gg} \mathrm{CH}_{4} / \mathrm{Mg} \\
\text { of coal }\end{array}$ \\
\hline \hline Ventilation & 6.0050 & 4.0234 & 6.4430 & 4.3168 & 5.8011 & 3.8868 \\
\hline $\begin{array}{l}\text { From methane } \\
\text { drainage }\end{array}$ & $\mathrm{NE}$ & $\mathrm{NE}$ & 0.5962 & 0.3994 & 0.9927 & 0.6651 \\
\hline $\begin{array}{l}\text { From post-mining } \\
\text { processes }\end{array}$ & 1.4810 & 0.9923 & 1.0200 & 0.6834 & 0.4288 & 0.2873 \\
\hline $\begin{array}{l}\text { From production } \\
\text { wastes }\end{array}$ & 0.0649 & 0.0435 & 0.0630 & 0.0422 & 0.0289 & 0.0194 \\
\hline $\begin{array}{l}\text { From abandoned } \\
\text { mines }\end{array}$ & $\mathrm{NE}$ & $\mathrm{NE}$ & 0.0489 & 0.0328 & $\mathrm{NE}$ & 0.0000 \\
\hline
\end{tabular}

$\mathrm{NE}$ - not estimated

based on the above-mentioned sources (NEIC 2009; NEATS 2009). In conformity with the procedure, an analysis has been carried out for the solid fuel sector of data uncertainty in accordance with the international guidelines included in the IPCC guidelines (2000) and determined as the methodology Tier 1. In the NEIC (2009), the results of this analysis were recapitulated; wider information about the accuracy of data and full uncertainty analysis can be found in the annex to this report. The uncertainty counted for individual categories of sources indicated a value of $41.9 \%$ for subcategory B.1. This included solid fuels, with methane emissions from hard coal systems also taken into account. The sources of emissions from all sectors are identified as main emissions sources on the basis of the assessment of their emissions level and/or trend. Coal mining in the assessment of methane emissions levels rated seventh place with respect to the share of methane emissions in 2007 in the total emissions not taking into consideration sector 5, and eighth place with regard to sector 5 .

\section{Methodology of estimating methane emissions connected with hard coal exploitation}

The methodology mentioned in the NEIC (2009) and in the publication of the SGI (2008) for estimating methane emissions from the network of hard coal mines in Poland is, at present, recommended and used in order to estimate greenhouse gas emissions.

The methane emission factors hitherto used in national emissions inventories for individual sources in the hard coal mining industry according to Kwarciński et al. (2005) and 
presented in two methodical works of Gawlik et al. (1994, 1995, 2000, 2001, 2002) require verification. Both the authors of the above-mentioned works and the IPCC 2006 recommendations regarding the estimation of methane emissions from the hard coal mining industry characterize:

- methane emissions during the coal exploitation process (underground emissions ventilation emissions, emissions from degasification systems),

- methane emissions in post-exploitation processes (surface emissions).

Each of the identified emissions sources should be treated independently, and therefore the estimation from each source is performed separately using the formula:

$$
E=Q_{w} \cdot W_{e}
$$

where:

$E$ - emission quantity from the given emission source $\left(\mathrm{m}^{3}\right)$,

$Q_{w}-$ coal output quantity $(\mathrm{Mg})$

$W_{e}-$ emission factor $\left(\mathrm{m}^{3} / \mathrm{Mg}\right)$.

In such a formulation, the emissions factor determines the volume of methane released into the atmosphere per mass unit $(\mathrm{Mg})$ of mined coal. Given the reporting requirements, the methane volume is converted into a mass $(\mathrm{Gg})$ unit with the application of the coefficient of conversion $0.67\left(\mathrm{Mg} / 10^{6} \mathrm{~m}^{3}\right)$ (IPCC 1997).

The recommendations of IPCC 2006 stressed improvements in the assessment of emission factors. According to the degree of recognition of mined coal seams' methane content and the accessibility of survey results, the following methods of estimating methane emissions from the hard coal mining industry are recommended:

1. Method of world averages.

2. Specific method for the country (coal basin).

3. Specific method for individual mines.

These methods differ considerably with respect to the accuracy of emission estimation.

1. The method of world averages (the least accurate method) recommends the adoption of emission factors based on global averages, the ventilation emission factor from the level of $10 \mathrm{~m}^{3} / \mathrm{Mg}$ (low emissions) up to $25 \mathrm{~m}^{3} / \mathrm{Mg}$, and the emission factor from post-exploitation processes from the level of $0.9 \mathrm{~m}^{3} / \mathrm{Mg}$ (low emissions) up to $4.0 \mathrm{~m}^{3} / \mathrm{Mg}$ (high emissions).

2. The specific method for the country (coal basin) is recommended for countries (coal basins), where a limited quantity of data is available which, however, enables analysts to take into account different characteristics of gas conditions in individual basins. In this case, it is recommended to use the rectilinear regression equation to estimate ventilation emissions:

$$
W_{w}=a_{0}+a_{1} \cdot M_{a v g}
$$


where:

$W_{w} \quad-$ ventilation emission factor $\left[\mathrm{m}^{3} / \mathrm{Mg}\right]$,

$a_{0}, a_{1}-$ equation coefficients,

$M_{\text {avg }}$ - average methane content of mined coal $\left[\mathrm{m}^{3} / \mathrm{Mg}\right]$.

3. The specific method for mines can be used in cases where access is available to detailed measurement results of the methane content of coal seams and data related to methane emissions from mines.

In Poland, the ventilation emission factors for individual mines can be calculated on the basis of reports from mine ventilation services, which are included in the Annual Report... (2002-2011). The total emissions in the case of hard coal mines in Poland constitute the sum of the ventilation emissions and methane capture by degasification systems.

The emissions from methane drainage systems in this method are understood as the difference between the quantity of methane captured by methane drainage systems and methane used. At the same time, the estimation methodology must be presented as well as a separate specification of the methane emissions which would not occur if there was a lack of methane drainage.

\section{Modifying the methodology of methane emissions estimation connected with hard coal exploitation in Poland}

The proposed new methodology for estimating methane emissions from hard coal mines, in conformity with the nomenclature applied by IPCC 2006, should be counted among specific methods for mines.

The underground stage the estimation of methane emissions from each specific source was conducted in an independent manner. All conducted calculations were intended to determine the dependence coefficients of emissions from individually identified sources taking into account data concerning the quantity of coal output and the methane content of the mine.

Modification of IPCC (2006) methods of estimating methane emissions from ventilation systems and degasification systems for hard coal mines (those active and abandoned) in Poland assume that the methane emission factor is calculated on the basis of methane coal mine (CMM) output and actual values of absolute methane content.

Estimations of ventilation emissions for individual mines were calculated on the basis of the formula:

$$
E_{w}=W_{e} \cdot Q
$$

where:

$Q$ - hard coal output in the CMM coal mines $[\mathrm{Mg}]$,

$W_{e}-$ ventilation emission factor $\left[\mathrm{m}^{3} \mathrm{CH}_{4} / \mathrm{Mg}\right]$. 
Estimation of methane emissions from methane drainage systems is the value of emissions from losses of captured methane using measurements carried out in the mines. These emissions are also determined as the difference between the captured and utilised methane.

The range of data applied in the new methodology of methane emissions estimation for the hard coal mining industry proposed in the present study concern data on the scale of individual mines. The range and sources of the information considered and the results of measurement are as follows:

1. The quantity of methane from ventilation systems given annually by every hard coal mine (in $\mathrm{m}^{3} \mathrm{CH}_{4}$ /year) was adopted on the basis of data presented in the Annual Report... (2002-2011).

2. The quantity of methane captured in the mine given annually by every hard coal mine (in $\mathrm{m}^{3} \mathrm{CH}_{4} /$ year) was adopted on the basis of data presented in the Annual Report... (2002-2011).

3. The quantity of methane emitted into the atmosphere from methane drainage systems given annually by every hard coal mine (in $\mathrm{m}^{3} \mathrm{CH}_{4}$ /year) was adopted on the basis of data presented in the Annual Report... (2002-2011).

4. Yearly average temperature of ventilation air (return air) measured at the point of volume measurement. Because of the lack of data from direct measurements, a temperature equal to $30^{\circ} \mathrm{C}$ was adopted (according to Kwarciński et al. 2005).

5. The yearly average temperature of mine gas emitted from methane drainage systems is measured at the point of its volume measurement. Because of the lack of data from direct measurement, a temperature of $30^{\circ} \mathrm{C}$ was adopted (according to Kwarciński et al. 2005).

6. The quantity of hard coal exploitation was adopted on the basis of data presented in the Annual Report... (2002-2011).

The final value of methane emissions from ventilation and degasification systems is obtained after the conversion of reported individual mines values of methane emissions in standard conditions $\left(293^{\circ} \mathrm{K}\right)$. This conversion is carried out using the formula:

$$
E_{w(N)}=E_{w} \cdot 293 /\left(273+t_{p}\right)
$$

where:

$E_{w(N)}$ - ventilation emissions converted into standard conditions $\left(20^{\circ} \mathrm{C}\right)\left[\mathrm{m}^{3}\right]$,

$E_{w}-$ ventilation emissions $\left[\mathrm{m}^{3}\right]$,

$t_{p} \quad-$ yearly average temperature of ventilation air $\left[{ }^{\circ} \mathrm{C}\right]$.

The specification of final ventilation emissions values (converted into standard conditions $-293^{\circ} \mathrm{K}$ ) and calculated emissions factors for individual hard coal mines are presented in Table 4.

Ventilation emissions from mines which did not specify ventilation emissions were not estimated. 
TABLE 4

Estimations of methane emissions from the hard coal mining industry in mines from 2001-2010

TABELA 4

Zestawienie wydobycia i emisji metanu z węgla kamiennego kopalń metanowych w latach 2001-2010

\begin{tabular}{|c|c|c|c|c|c|}
\hline Year & Type of emissions & $\begin{array}{c}\text { Output of CMM } \\
\text { coal mines, } \\
{\left[10^{6} \mathrm{Mg}\right]} \\
\end{array}$ & $\begin{array}{c}\text { Methane emissions } \\
\text { in standard conditions } \\
{\left[10^{6} \mathrm{Nm}^{3}\right]}\end{array}$ & $\begin{array}{c}\text { Emission } \\
\text { factor } \\
{\left[\mathrm{m}^{3} \mathrm{CH}_{4} / \mathrm{Mg}\right]}\end{array}$ & $\begin{array}{c}\text { Methane } \\
\text { emissions } \\
{[\mathrm{Gg}]}\end{array}$ \\
\hline 1 & 2 & 3 & 4 & 5 & 6 \\
\hline \multirow{3}{*}{2001} & Ventilation emissions & \multirow{3}{*}{72.366} & 515.314 & 7.010 & 345.260 \\
\hline & $\begin{array}{l}\text { Emissions from } \\
\text { degasification systems }\end{array}$ & & 85.185 & 0.990 & 57.074 \\
\hline & $\begin{array}{l}\text { Underground coal } \\
\text { mining industry }\end{array}$ & & 600.499 & 8.000 & 402.334 \\
\hline \multirow{3}{*}{2002} & Ventilation emissions & \multirow{3}{*}{72.129} & 538.660 & 7.284 & 360.902 \\
\hline & $\begin{array}{l}\text { Emissions from } \\
\text { degasification systems }\end{array}$ & & 82.894 & 0.996 & 55.539 \\
\hline & $\begin{array}{l}\text { Underground coal } \\
\text { mining industry }\end{array}$ & & 621.554 & 8.280 & 416.441 \\
\hline \multirow{3}{*}{2003} & Ventilation emissions & \multirow{3}{*}{65.708} & 548.487 & 8.457 & 367.486 \\
\hline & $\begin{array}{l}\text { Emissions from } \\
\text { degasification systems }\end{array}$ & & 96.612 & 1.353 & 64.730 \\
\hline & $\begin{array}{l}\text { Underground coal } \\
\text { mining industry }\end{array}$ & & 645.099 & 9.809 & 432.217 \\
\hline \multirow{3}{*}{2004} & Ventilation emissions & \multirow{3}{*}{69.167} & 556.020 & 7.640 & 372.534 \\
\hline & $\begin{array}{l}\text { Emissions from } \\
\text { degasification systems }\end{array}$ & & 102.569 & 1.281 & 68.721 \\
\hline & $\begin{array}{l}\text { Underground coal } \\
\text { mining industry }\end{array}$ & & 658.589 & 8.921 & 441.255 \\
\hline \multirow{3}{*}{2005} & Ventilation emissions & \multirow{3}{*}{67.347} & 576.200 & 8.075 & 386.054 \\
\hline & $\begin{array}{l}\text { Emissions from } \\
\text { degasification systems }\end{array}$ & & 107.446 & 1.500 & 71.989 \\
\hline & $\begin{array}{l}\text { Underground coal } \\
\text { mining industry }\end{array}$ & & 683.646 & 9.575 & 458.043 \\
\hline \multirow{3}{*}{2006} & Ventilation emissions & \multirow{3}{*}{64.518} & 537.592 & 8.332 & 360.187 \\
\hline & $\begin{array}{l}\text { Emissions from } \\
\text { degasification systems }\end{array}$ & & 126.870 & 1.966 & 85.003 \\
\hline & $\begin{array}{l}\text { Underground coal } \\
\text { mining industry }\end{array}$ & & 664.462 & 10.298 & 445.190 \\
\hline
\end{tabular}


TABLE 4 cont

TABELA $4 \mathrm{~cd}$

\begin{tabular}{|c|c|c|c|c|c|}
\hline 1 & 2 & 3 & 4 & 5 & 6 \\
\hline \multirow{3}{*}{2007} & Ventilation emissions & \multirow{3}{*}{62.465} & 590.090 & 9.427 & 395.361 \\
\hline & $\begin{array}{l}\text { Emissions from } \\
\text { degasification systems }\end{array}$ & & 99.630 & 1.637 & 66.752 \\
\hline & $\begin{array}{l}\text { Underground coal } \\
\text { mining industry }\end{array}$ & & 689.720 & 11.064 & 462.112 \\
\hline \multirow{3}{*}{2008} & Ventilation emissions & \multirow{3}{*}{$\mathbf{5 7 . 5 3 7}$} & 586.677 & 10.288 & 393.074 \\
\hline & $\begin{array}{l}\text { Emissions from } \\
\text { degasification systems }\end{array}$ & & 113.816 & 2.137 & 76.256 \\
\hline & $\begin{array}{l}\text { Underground coal } \\
\text { mining industry }\end{array}$ & & 700.492 & 12.426 & 469.330 \\
\hline \multirow{3}{*}{2009} & Ventilation emissions & \multirow{3}{*}{53.271} & 576.243 & 11.150 & 386.083 \\
\hline & $\begin{array}{l}\text { Emissions from } \\
\text { degasification systems }\end{array}$ & & 96.990 & 1.815 & 64.983 \\
\hline & $\begin{array}{l}\text { Underground coal } \\
\text { mining industry }\end{array}$ & & 673.233 & 12.966 & 451.066 \\
\hline \multirow{3}{*}{2010} & Ventilation emissions & \multirow{3}{*}{52.184} & 559.852 & 11.050 & 375.101 \\
\hline & $\begin{array}{l}\text { Emissions from } \\
\text { degasification systems }\end{array}$ & & 91.671 & 1.777 & 61.420 \\
\hline & $\begin{array}{l}\text { Underground coal } \\
\text { mining industry }\end{array}$ & & 651.524 & 12.826 & 436.521 \\
\hline
\end{tabular}

Emissions from methane drainage systems $\left(E_{o}\right)$ of each of the CMM mines where methane drainage is conducted (otherwise called loss emissions) are calculated as the difference between the quantity of captured methane $\left(M_{u i}\right)$ and the quantity of utilized methane $\left(M_{w i}\right)$ (or burnt):

$$
E_{o}=M_{u i}-M_{w i}\left[\mathrm{~m}^{3}\right]
$$

The final value of methane emissions from degasification systems is obtained after the conversion of the values specified by individual mines of methane emissions into standard conditions $\left(293^{\circ} \mathrm{K}\right)$. This conversion is carried out using formula (4).

The emissions from methane drainage systems were estimated for the individual years 2001-2010. 


\section{Inventory of methane emissions from ventilation and degasification systems of CMM coal mines in the USCB}

The new methodology proposed for estimating methane emissions from CMM coal mines, in conformity with the nomenclature applied by ICPP 2006, should be counted among specific methods for mines. The emissions from both sources are based on the results of measurements and studies conducted in individual hard coal mines. The calculated average national emission factors for the years 2001-2010 amounted to (Table 4):

- for ventilation emissions $-8.871 \mathrm{~m}^{3} / \mathrm{Mg}\left(7.010-11.050 \mathrm{~m}^{3} / \mathrm{Mg}\right)$,

- for emissions from methane drainage systems $-1.545 \mathrm{~m}^{3} / \mathrm{Mg}\left(0.990-2.137 \mathrm{~m}^{3} / \mathrm{Mg}\right)$.

In spite of the reduction in coal output from the Polish mining industry, since the year 2008 the average emissions factor from the hard coal industry has maintained a constant level. The analyses performed also underline the permanent trend (avg. $440 \mathrm{Gg}$ ) of methane emissions in the entire analysed period of the years 2001-2010.

The main assumption of the calculations and methane emissions inventory (Table 4) was the approach in accordance with IPCC 2006 (Tier 3) using country specific methods. A detailed analysis of methane emissions from coal mines in Poland showed there is a significant difference between the total volume of production and the volume of production in methane mines only (Table 5). That is why the analysis of variability coefficients of methane emissions in hard coal mines in Poland between 2001-2010 was conducted. It was

TABLE 5

Uncertainty in the measurement of methane emissions activity in hard oal mines

TABELA 5

Niepewność szacowania emisji metanu z węgla kamiennego kopalń

\begin{tabular}{||c|c|c|c||}
\hline \hline Years & $\begin{array}{c}\text { Hard coal output } \\
\text { in the coal mines } \\
{\left[10^{6} \mathrm{Mg}\right]}\end{array}$ & $\begin{array}{c}\text { Hard coal output } \\
\text { in the CMM coal mines } \\
{\left[10^{6} \mathrm{Mg}\right]}\end{array}$ & $\begin{array}{c}\text { Uncertainty in measurement } \\
\text { of methane emission activity } \\
{[\%]}\end{array}$ \\
\hline \hline 2001 & 102.78 & 72.37 & 27.44 \\
\hline 2002 & 102.07 & 72.13 & 27.13 \\
\hline 2003 & 100.41 & 65.71 & 34.33 \\
\hline 2004 & 99.17 & 69.17 & 26.74 \\
\hline 2005 & 97.17 & 67.35 & 27.14 \\
\hline 2006 & 94.27 & 64.52 & 29.49 \\
\hline 2007 & 87.40 & 62.47 & 27.37 \\
\hline 2008 & 83.40 & 57.54 & 30.34 \\
\hline 2009 & 77.27 & 53.27 & 31.73 \\
\hline 2010 & 76.15 & 52.18 & 32.27 \\
\hline
\end{tabular}


considered to be the total volume of production and the volume of production in methane mines as the basis for the analyses.

Table 5 presents the total coal output value and value of coal output in methane mines, and each of the years 2001-2010 was assigned its variability coefficient. On this basis it was concluded that, taking into consideration the output from methane coal mines, the uncertainty of estimating methane emissions activity decreases by approx 29.40\% (Patyńska 2012).

The final compilation of the obtained values was presented based on the methodology proposed for estimating methane emissions in Polish coal mines. The values meet IPCC 2006 requirements, but they are based on actual data from methane coal mines. The differences in estimating methane ventilation emission in Polish coal mines stem from the difference between the actual value of methane ventilation emissions in Polish coal mines and the value calculated according to IPCC 2006 (Table 6). The value of the emission factors in both cases is identical. The relative error of predictions for methane emissions estimation in coal mines according to both the Polish method and that proposed by IPCC 2006 is approximately 0.651 .

TABLE 6

The difference in values for methane emissions vented from coal mines according to the Polish methodology and IPCC (2006)

TABELA 6

Porównanie oszacowanej emisji metanu według metody krajowej i zalecanej przez IPCC (2006)

\begin{tabular}{|c|c|c|c|c|c|c||}
\hline Years & $\begin{array}{c}\text { Hard coal } \\
\text { output in the } \\
\text { CMM coal } \\
\text { mines } \\
{\left[10^{6} \mathrm{Mg}\right]}\end{array}$ & $\begin{array}{c}\text { Emission } \\
\text { factor } \\
{\left[\mathrm{m}^{3} / \mathrm{Mg}\right]}\end{array}$ & $\begin{array}{c}\text { Actual emissions of } \\
\text { methane according } \\
\text { to the Polish } \\
\text { methodology } \\
{[\mathrm{Gg}]}\end{array}$ & $\begin{array}{c}\text { Methane } \\
\text { emissions by } \\
\text { IPCC } \\
{[\mathrm{Gg}]}\end{array}$ & $\begin{array}{c}\text { The } \\
\text { difference in } \\
\text { values for } \\
\text { emissions } \\
{[\mathrm{Gg}]}\end{array}$ & $\begin{array}{c}\text { Relative error } \\
\text { of } \\
\text { by IPCC } \\
{[\%]}\end{array}$ \\
\hline \hline 2001 & 72.370 & 7.010 & 345.260 & 339.900 & 5.360 & 1.552 \\
\hline 2002 & 72.130 & 7.284 & 360.902 & 352.015 & 8.887 & 2.463 \\
\hline 2003 & 65.710 & 8.457 & 367.486 & 372.325 & -4.839 & -1.317 \\
\hline 2004 & 69.170 & 7.640 & 372.534 & 354.067 & 18.467 & 4.957 \\
\hline 2005 & 67.350 & 8.075 & 386.054 & 364.380 & 21.674 & 5.614 \\
\hline 2006 & 64.520 & 8.332 & 360.187 & 360.179 & 0.008 & 0.002 \\
\hline 2007 & 62.470 & 9.427 & 395.361 & 394.566 & 0.795 & 0.201 \\
\hline 2008 & 57.540 & 10.288 & 393.074 & 396.621 & -3.547 & -0.902 \\
\hline 2009 & 53.270 & 11.150 & 386.083 & 397.954 & -11.871 & -3.075 \\
\hline 2010 & 52.180 & 11.050 & 375.101 & 386.315 & -11.214 & -2.989 \\
\hline Average emission values & $\mathbf{8 . 8 7 1}$ & $\mathbf{3 7 4 . 2 0 4}$ & $\mathbf{3 7 1 . 8 3 2}$ & $\mathbf{2 . 3 7 2}$ & $\mathbf{0 . 6 5 1}$ \\
\hline \hline
\end{tabular}




\section{Conclusions}

In general, it is necessary to assume that IPCC 2006 guidelines are appropriate to assess levels of methane emissions. Yet it should be emphasized that the estimation method refers only to the methane coal mines' output and is based on the measurements of methane content. The bases are data on the uncertainty of estimating methane emissions activity. The average value of uncertainty of methane emissions activity decreased by approximately $29.40 \%$ when it was calculated using methane coal mines' output instead of the output of all coal mines.

Updating the proposed methods (IPCC 2006) of estimating methane emissions from ventilation and degasification systems of hard coal mines (those active and abandoned) in Poland, it is assumed the methane emission factor $(E F)$ is calculated on the basis of methane coal mine output and actual values of absolute methane content.

Using the results of the Annual Report... (for the years 2001-2010), national emission factors were determined for the following emissions sources in hard coal mines:

— from ventilation systems,

- from methane drainage systems.

Figure 1 presents the distribution of emission factors (for 2 sources) between 2001 and 2010 from methane coal mines in Poland. It shows a trend in agreement with the distribution of the polynomial function of fitness $R_{2}=0.9889$. Verifying the method of estimating methane emissions for Polish coal mines resulted in the following equation:

$$
E F=-0.0045 \cdot Q^{2}+0.3104 \cdot Q+9.1473
$$

where:

$E F-$ Emission Factor $\left[\mathrm{m}^{3} / \mathrm{Mg}\right]$

$Q$ - Hard coal output in the CMM coal mines $\left[10^{6} \mathrm{Mg}\right]$.

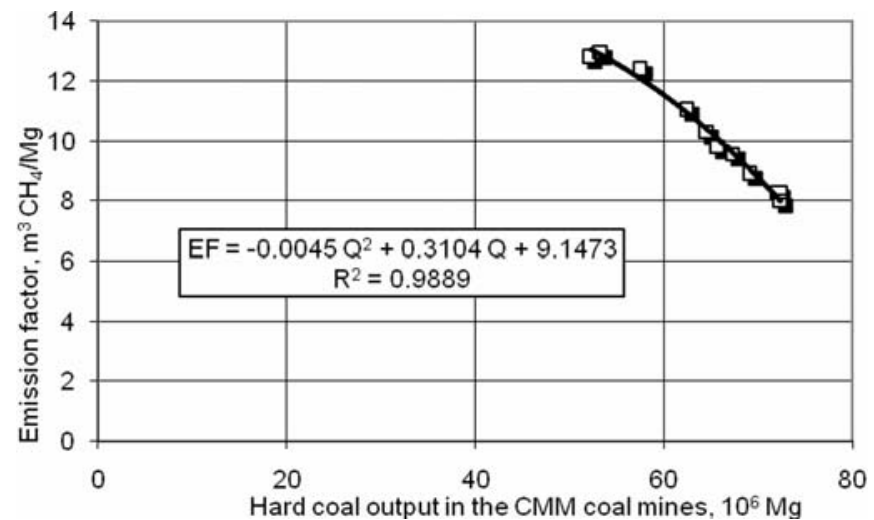

Fig. 1. Distribution of mining methane emission factors for hard coal mines in the years 2001-2010

Rys. 1. Rozkład wskaźnika emisji metanu z węgla kamiennego na tle wielkości wydobycia z kopalń metanowych w latach 2001-2010 
The estimated emission factor $(E F)$ of the methane can be used in the methodology of methane emissions estimation. This methodology could be further employed to estimate the emissions of methane in subsequent years of coal mine exploitation.

This document was created by the project Lowcarb (Central Mining Institute, Katowice 2010-2013 ) "Low carbon mine site energy initiatives"; Research Programme of the Research Fund for Coal and Steel; Kontract no. RFCR-CT-2010-00004

\section{REFERENCES}

Annual Report... 2002-2011 - Annual Report (for the years 2001-2010) on the State of Basic Natural and Technical Hazards in the Hard Coal Mining Industry. Gaz hazard. Publ. Central Mining Institute, Katowice 2002-2011, p. 20-40.

G a w lik L. et al., 1994 - Determination of greenhouse gas emission sources connected with the exploitation of the coal system (hard and brown coal) along with the determination of emission factors in sources of the emission system, calculation of emissions for the last year using the indications of the OECD/IPCC methodology and given methodologies of current information updating. National Fund of Environmental Protection, Warsaw (non-published).

Gawlik L., Grzybek I., 1995 - Methodology of estimation of methane emissions connected with coal exploitation in Poland. Gospodarka Surowcami Mineralnymi. Volume II, Booklet 3, p. 371-393.

Gawlik L., Grzybek I., 2000 - Investigation results and recommendations for uncertainty reduction and clarity improvement of inventory of fugitive methane emissions from the hard coal system. Workshop: Improvement of National Inventory of Greenhouse Gases in Poland FEWE, Warsaw, p. 1-30.

Gawlik L., Grzybek I., 2001 - Detailed investigations into emission sources and capture for the inventory of greenhouse gas emissions for 1999 with respect to fugitive emissions from the coal system. Cracow, p. $1-40$.

Gaw lik L., Grzybek I., 2002 - Estimation of methane emissions in Polish Basins (Hard Coal System). Polish Academy of Sciences. Publ. IGSMiE. Cracow, p. 1-98.

Instruction... 2000 - Dynamic prediction of longwall absolute methane emissions (technical hand-book). Instruction of Central Mining Institute No 14, Katowice.

IPCC 1997 - Revised 1996 IPCC Guidelines for National Greenhouse Gas Inventories. Reference Manual.

IPCC 2000 - Good Practice Guidance and Uncertainty Management in National GHG Inventories.

IPCC 2006 - Guidelines for National Greenhouse Gas Inventories. Vol. 2, Energy.

NAETS 2009 - Database of the National Administrator of the Emissions Trading Scheme, containing information about installations covered by the emissions trading scheme along with data originating from verified reports about the annual $\mathrm{CO}_{2}$ emissions. Institute of Environmental Protection. Warsaw, p. 1-167.

NEIC 2009 - National inventory of greenhouse gas emissions and absorption for 2007. Report prepared for the needs of the United Nations Framework Convention on Climate Change and Kyoto Protocol. NATIONAL ADMINISTRATOR OF THE EMISSIONS TRADING SCHEME. NATIONAL EMISSIONS INVENTORY CENTRE. Institute of Environmental Protection. Warsaw.

Kidybiński A., Patyńska R., 2008 - Analysis of gas-geodynamic phenomena in hard coal mines in Poland and in the world. Monograph. Scientific Works of Central Mining Institute, Katowice, p. 1-110.

K o n o p k o W., ed., 2010 - Conditions of safe exploitation of coal seams threatened by methane, rockbursts and fires. Publ. Central Mining Institute, Katowice, p. 116-110.

Kwarcińs ki J., et al., 2005 - Assessment of real methane emissions into the atmosphere caused by hard coal exploitation. State Geological Institute, Sosnowiec, p.1-123 (non-published).

Kyoto Protocol... 1997 - Kyoto Protocol for United Nations Framework Convention on Climate Change. IIIrd $\mathrm{C}$ onf. of Paris. 
Order... 2002 - Order of the Minister of Internal Affairs and Administration of 14 June 2002 on natural hazards in mines (Journal of Laws of the Republic of Poland of 1 July 2002, item 841 along with the amendment introduced by the Order of the Minister of Internal Affairs and Administration changing the order on natural hazards in mines (with respect to methane hazard the changes concern the article 12, section 1)).

Pa ty ńs ka R., 2010 - Rock mass structure and its influence on gas parameters of deposits in which coal outburst and squealer hazard occur. III Traditional International Colloquium on Geomechanics and Geophysics, Ostavice 06-07.05.2010 r., Czech Republic, Publishers: Akademie vęd České republiky, Ustav Geoniky, v.v.i. (Academy of Science of the Czech Republic, Institute of Geonics), Ostrava, p. 207-225.

Patyńs ka R., 2012 - Uncertainty in measurement of methane emission activity in CMM in Poland in the years 2001-2010. Mat. XIX International Conrefernce Science of Technical. Publ. Central Mining Insitute, Katowice, p. 287-298.

SGI 2008 - Balance of resources of minerals and underground waters in Poland. State for the year 2007. State Geological Institute, Warsaw.

EMISJA METANU Z UKLADÓW WENTYLACYJNYCH I ODMETANOWANIA KOPALŃ WĘGLA KAMIENNEGO W POLSCE W LATACH 2001-2010

\section{Słowa kluczowe}

Górnictwo, węgiel kamienny, emisja metanu, wskaźnik emisji

\section{Streszczenie}

W latach 2001-2010 produkcja oraz liczba funkcjonujących kopalń węgla kamiennego w polskim górnictwie węgla kamiennego uległa znacznemu zmniejszeniu. Wydobycie węgla ze $102,78 \cdot 10^{6} \mathrm{Mg}$ ograniczono do $76,15 \cdot 10^{6} \mathrm{Mg}$. Eksploatacja pokładów realizowana w 43 zakładach górniczych w roku 2001, na skutek likwidacji oraz połączenia kopalń, w roku 2010 dotyczyła 29 kopalń. Liczba 30 kopalń metanowych w roku 2001, w których wydobywano węgiel na poziomie $72,37 \cdot 10^{6} \mathrm{Mg}$, w roku 2010 wynosiła 21 kopalń, produkujących $52,18 \cdot 10^{6} \mathrm{Mg}$ węgla.

Pomimo spadku produkcji węgla oraz malejącej liczby kopalń w Polsce wentylacyjna emisja metanu z procesów eksploatacji węgla kopalń metanowych od roku 2001 wzrosła o około $50 \mathrm{~m}^{3} / \mathrm{Mg}$. W miarę upływu lat, wysiłki na rzecz odmetanowania niosa jednak pozytywny skutek. Pomimo wzrostu „strat” metanu w procesie odmetanowania, z roku na rok zwiększa się ilość metanu ujętego systemami odmetanowania.

Z rozeznania i przeglądu literaturowego dotyczącego zagadnień związanych $\mathrm{z}$ emisją metanu w Polsce wynika, że w 2009 roku opublikowano Raport Krajowej Inwentaryzacji Emisji i Pochłaniania gazów cieplarnianych za rok 2007. Z Raportu Krajowej Inwentaryzacji... wynika, że brak jest danych szczegółowych dotyczących wskaźników emisji metanu z kopalń węgla kamiennego dla polskiego górnictwa. W związku z tym, przygotowano i obliczono szczegółowo emisje metanu z kopalń metanowych w Polsce. Zastosowana metodyka szacowania metanu wykonana została dla dwóch podstawowych źródeł jego emisji. Obliczono emisję metanu w trakcie procesu eksploatacji węgla jako emisję wentylacyjną oraz emisję z układów odgazowania. Takie podejście wynikało z wytycznych IPCC z roku 2006.

Aktualizacja proponowanych metod IPCC (2006) szacowania emisji metanu z układów wentylacyjnych i z układów odmetanowania kopalń węgla kamiennego (czynnych i zlikwidowanych) w Polsce polega na założeniu, że wskaźnik emisji metanu $(E F)$ obliczamy, opierając się na wydobyciu z koplań metanowych oraz rzeczywistych wielkościach metanowości bezwzględnej. Rezultat modyfikacji metody szacowania emisji metanu z procesów górniczych dla polskich metanowych koplań węgla kamiennego to równanie wskaźnika emisji metanu.

W górnictwie polskim, od roku 2008 średni wskaźnik emisji z systemu węgla kamiennego utrzymuje się na stałym poziomie około $10 \mathrm{~m}^{3} \mathrm{CH}_{4} / \mathrm{Mg}$. Uzyskane wyniki obliczeń emisji metanu w całym analizowanym okresie lat 2001-2010, mieszczą się w granicach 402-462 Gg (śr. 441,45 Gg). 


\title{
METHANE EMISSIONS FROM VENTILATION AND DEGASIFICATION SYSTEMS OF HARD COAL MINES
} IN POLAND IN THE YEARS 2001-2010

$$
\text { Key words }
$$

Mining, coal mine methane, methane emission, emission factor

\begin{abstract}
Summarising the statistics of the Annual Report... (2002-2011), it can be stated that between 2001 and 2010 the number of and output from operating hard coal mines in the Polish hard coal mining industry experienced a considerable decrease. Coal output of $102.78 \cdot 10^{6} \mathrm{Mg}$ was reduced to $76.15 \cdot 10^{6} \mathrm{Mg}$. The exploitation of seams was realised in 43 mines in 2001, but because of closures and the merging of mines this fell to 29 by 2010 . There were 30 Coal Mine Methane (CMM) mines in 2001 producing coal at a level of $72.37 \cdot 10^{6} \mathrm{Mg}$, falling to 21 mines producing $52.18 \cdot 10^{6} \mathrm{Mg}$ of coal by 2010 .

In spite of this drop in coal production and the decreasing number of mines in the Upper Silesian Coal Basin (USCB) in Poland, methane emissions from coal exploitation processes in CMM mines since 2001 increased by about $50 \mathrm{~m}^{3} / \mathrm{Mg}$ by 2010 . Over time, efforts at methane drainage have priduced positive effects. Every year, the quantity of methane captured by methane drainage systems and the quantity of utilised methane increases.

The National Greenhouse Inventory (NEIC) 2007, published in 2009, showed there was no detailed data concerning methane emissions from collieries in the Polish mining industry. It was therefore necessary to study and meticulously calculate methane emissions in methane coal mines of the USCB in Poland. The applied methodology for estimating methane emissions from the USCB coal mining industry considered the two basic sources of its emission? methane emissions during the mining process and ventilation emission and drainage systems emissions. Such an approach resulted from the Intergovemmental Panel on Climate Change (IPCC) guidelines of 2006.

Updating the proposed methods (IPCC 2006) of estimating methane emissions from ventilation systems and degasification systems of hard coal mines (those active and abandoned) in Poland assumes the methane emission factor $(E F)$ is calculated on the basis of methane coal mine output and actual values of methane emisions. Modifying the method of estimating methane emissions during the mining process for Polish coal mines resulted in the equation of methane emissions factor $E F$.

Despite a decrease in coal production between 2001 and 2010, since 2008 the average emission factor from the hard coal industry remains steady at a level of approximately $10 \mathrm{~m}^{3} \mathrm{CH}_{4} / \mathrm{Mg}$. The obtained summary results of calculating methane emissions in the Polish coal mining industry throughout the analysed period are from 402-462 Gg (avg. 441.45 Gg).
\end{abstract}


